\section{$1 \mathrm{P033}$}

\section{タンパク質立体構造の確率的比較}

○小池 亮太郎 ${ }^{1,2}$ 、木寺 詔紀 ${ }^{2}$ ( 1 京大院 - 理、 ${ }^{2}$ 横浜市大院 . 総合理学)

タンパク質立体構造の Comparative Study は、立体棈造の分類や特徵 抽出によって、立体構造-機能相関を明らかにし、さらに構造・機能予 測を与えるための有力な方法である。その Comparative Study で最も 基本となる方法は、構造類似部位の Alignmentを与える方法である。 構造 Alignment 構築のさい問題となるのが準最適 Alignment の存在 である。準最適な Alignmentが多数存在する系では Alignmentごとに 対応付けられる残基対が異なり、対応関係を一意に決定することはで きず、特徴抽出のさいの障害となる。この問題を回避するために発表 者らは残基間の対応関係を確率で記述する Probabilistic Alignment を構築する方法を開発した。この方法は 1 つの Alignmentを与えるこ ととSpin 系において1つの状態を決めることが等価であることを利 用し、構造情報を評価する 2 体の相互作用の項を 1 体の平均場ポテン シャルとして近似することでSpin 系における分配関数を求め、Spin 系における各状態、すなわち Alignmentを自由エネルギーなどから統 計的に評価するものである。この自由エネルギーを用いることで、準 最適な Alignment の存在する系において、単一の Alignment からな る構造類似性スコアよりよい評価を与えることが期待される。また、 このSpin 系のアナロジーを使う方法は、一般的に受け入れられてき たSSAPの基礎をなす Double Dynamic Programming 法を絶対零度 における極限とし、それを有限温度に搪張したものとして位置付ける ことができる。本発表では Probabilistic Alignment, 構筑の方法論を 説明し、この比較法をいくつかのタンパク質立体構造に適用した結果 について発表する。また、準最適な Alignment が存在する系で単一 Alignment功なるSSAP スコアと本方法による自由エネルギーにつ いて議論する。

R. Koike and A. Kidera : Probabilistic Comparison of Protein Structure

\section{$1 \mathrm{P035}$}

\section{バクテリオロドプシンの X 線結晶構造解析の信憑性 一 X 線損傷の影響— \\ ○坂井 啓介 ${ }^{1}$ 、松井 耕宏 ${ }^{1}$ 、村上 緑 ${ }^{1}$ 、奥村 英夫 ${ }^{1}$ 、足立 伸 -2 城宜嗣 2 、神山勉 1,2 ( 1 名大院. 理学研究科、2 理研・ 播磨)}

X線結晶構造解析は結晶構造を求める手法として現在偪広く用い られているが、X線自身がその構造になんらかの影響を与え本来の構 造と異なったものを求めている可能性も考えられる。今回の発表では 当研究室で研究を行っているバクテリオロドプシン $(b R)$ において新 たに明らかになったX線損傷の影響について発表する。

$\mathrm{bR}$ は高度好塩菌に見出された膜蛋白質で、光エネルギーを利用し てプロトンを細胞の内側から外側へと輸送する。当研究室ではbRの 構造解析を継続的に研究してきており、現在、K反沁中間体について の構造解析を行っている。K中間体の捕捉率を把握するため、SPring8の BL44B2 に低温顕微分光装置を構築し、可視域の吸収スペクトル とX 線回折との同時測定と行った。 $100 \mathrm{~K} て ゙ \mathrm{~K}$ 中間体を捕捉し同時測 定を行ったところX線照射に伴い吸収スペクトルが大きく変化する という現象が見出された。すなわち $580 \mathrm{~nm}$ の吸収带が減少し、510、 480、450nmにピークを持つ吸収帯が出現した。問題なのは吸収変化 の速さで、X線回折の完全なデータセットを収集するのに要する時間 内でも吸収スペクトルの変化が認められた。

X線によりどのような構造变化が引き起こされるかを明らかにす るため、基底状態の回折データを同一結晶から 3 セット収集した。回 折デー夕を分析したところ、特定の残基 (Asp85 など)が X 線の影复 を受けやすいことが示唆された。今後反応中間体の結晶構造解析を進 めていくうえで、X線損傷の影響を軽減させることは必要不可欠であ る。また bRに限らず、あらゆるX線結晶構造解析において X 線損傷 の問題は考慮すべき問題だと思われる。

K.Sakai,Y.Matsui,M,Murakami,H,Okumura,S.Adachi,Y.Shiro and T.Kouyama: Reliability of the X-ray Crystallographic analyses of bacteriorhodopsin -Effect of X-ray Damage-

\section{$1 \mathrm{P} 034$}

\section{分子の表面積及びそのデリバティブの計算}

○㮡 慶丈 ${ }^{1,2}$ 、升屋 正人 $^{3}$ ( ${ }^{1}$ 総研大 $\cdot$ 数物科学、 ${ }^{2}$ 分子研 $\cdot$ 理 論、 3 鹿児島大・総合情報処理センター)

タンパク質分子の立体構造形成機構についてはまだ十分に明らか にされていない。これを目的としてモンテカルロ法によるアミノ酸配 列の情報から分子の立体構造を予測する試みや分子動力学法による 立体構造予測シミュレーションなどが行われている。これらのシミュ レーションには構造エネルギーに加えて溶媒によるエネルギー及びそ のデリバティブの計算が必要となるが，計算に時間がかかるため大規 模なシミュレーションにはこれまで用いられていない. 本研究ではこ の溶媒のエネルギー及びそのデリバティブをタンパク質分子の表面積 及びそのデリバティブから近似的に求㝑法に着目し，これらを高 速に計算することにより溶媒によるエネルギー及びそのデリバティブ の計算の高速化を図ることにした。

タンパク質分子の表面積及びそのデリバティブを求める方法には大 きく分けて解析的解法と数值的解法の二つがある. 解析的解法では原 子の交わり方によっては計算機上では判別できないほど小さな距離や 角度を求める必要があり，このような場合には表面積及びそのデリバ テイブを求めることができない，そこで本研究では分子の構造によら ず安定して計算できる数值的解法によりタンパク質分子の表面皘及び そのデリバティブを計算することにした。開発したプログラムによる 表面積の計算では, 解析的解法と比較して十分な精度を保ちながら約 12 倍の計算速度を達成できた。またデリバテイブの計算では, 計算 速度が解析的解法に対して5倍程度となるものの, 分子の構造により 計算できないという解析的解法の欠点を持たず，蕨密に溶媒のエネル ギーを計算する方法と比べれば高速であった．本研究を応用すること により，溶媒によるエネルギー及びエネルギーのデリバディブの計算 が高速化され，これまで行うことができていない大規模なシミュレー ションが実現できる.

Y.Sakae and M.Masuya : A calculation method of the molecular surface area and its derivatives.

\section{$1 P 036$}

可逆的熱転移温度領域における膜タンパク質バクテ リオロドプシンのヒドロキシルアミン反応性と構造 の変化

○園山 正史、美宅 成樹（東京農工大·工）

光駆動プロトンポンプである膜タンパク質バクテリオロドプシン （bR）は、紫膜中で三㖏体構造を基本とした二次元結晶を形成してい

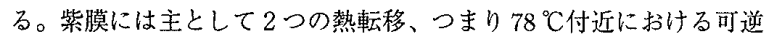
的な前転移と $96{ }^{\circ} \mathrm{C}$ 付近における不可逆的な主転移が存在することが 知られている。最近私たちのグループでは、可逆的な熱転移を示す $60-70{ }^{\circ} \mathrm{C}$ 温度領域において、暗中では変性が全くみられないのに 対し、本来は機能の発現を引き起こす可視光の照射により選択的に光 退色現象が生じることを見いたししたこのことは光機能中間体の不安 定化の可能性を示唆しており、この温度領域における構造変化に関す る研究は、機能中間体を含む bRの構造安定性を理解する上で重要で あると考えられる。

本研究では、光退色現象はシッフベースの加水分解反応であること に着目し、bRの安定性に対する水分子の影響を考えるために、水溶 性加水分解試薬であるとドロキシルアミンと bRの暗中に扔ける反応 性と、赤外分光法によるペプチド主鎖の水素-重水素交換の温度依存 性を詳細に検討している。さらに、この温度領域における詳細な構造 変化をいくつかの分光学的手法を用いて調べている。

これまでに、暗中におけるヒロドキシルアミンによる bRの退色反 応速度のアレニウスプロットを求めたところ、 $60{ }^{\circ} \mathrm{C}$ 付近を境にして 反応速度の温度依存性が顥著に変化することがわかった。アレニウス プロットの解析から、 $60{ }^{\circ} \mathrm{C}$ 以上の温度領域に扔ける頻度因子の著し い増大が自られ、このことは水分子のシッフベースへの accessibility の大きな増加を示唆している。一方反心の活性化エネルギーの増加も 見られている。ペプチド主鎖の水素-重水素交換といくつかの分光法 による構造变化の結果を含めて、総合的に $60-70{ }^{\circ} \mathrm{C}$ 温度領域に抢

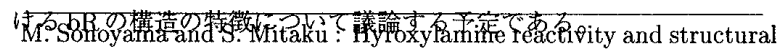
changes of the membrane protein bacteriorhodopsin in the reversible premelting temperature region 